\title{
LITERATUR REVIEW: KEMAMPUAN REPRESENTASI MATEMATIS MELALUI PENDEKATAN SPUR PADA PEMBELAJARAN MATEMATIKA
}

\author{
Hadijah $^{1)}$ \\ Stevanus Budi Waluya ${ }^{2}$ \\ Zaenuri Mastur ${ }^{3)}$ \\ 1), 2), 3) Program Studi Pendidikan Matematika, Universitas Negeri Semarang \\ Email: ${ }^{1)}$ hadijah1010@students.unnes.ac.id
}

\begin{abstract}
ABSTRAK
Artikel ini memiliki tujuan untuk mendeskripsikan mengenai kemampuan representasi matematis dengan memanfaatkan pendekatan SPUR. Penelitian dengan metode literature review berdasarkan kajian penelitian-penelitian terdahulu yang relevan mengenai kemampuan representasi matematis juga pendekatan SPUR. Dikaji dan diseleksi beberapa artikel yang diperoleh dari pencarian melalui aplikasi Publish or Perish 7. Adapun banyak artikel yang dikaji yaitu 13 artikel yang bersumber dari jurnal nasional maupun jurnal internasional. Hasil kajian menunjukkan bahwa melalui pendekatan SPUR dapat meningkatkan dan melatih siswa dalam menyelesaikan masalah matematika. Salah satu kemampuan yang siswa harus miliki adalah kemampuan representasi matematis, agar dengan mudah mempresentasikan solusi dari suatu masalah.
\end{abstract}

Kata kunci: Representasi Matematis, Pendekatan SPUR, Pendidikan, Matematika.

\begin{abstract}
This article aims to describe the mathematical representation ability using the SPUR approach. Research using the literature review method is based on studies of previous relevant studies regarding mathematical representation abilities as well as the SPUR approach. Several articles were reviewed and selected from google searches and the Publish or Perish 7 application. There were 13 articles that were studied from national and international journals. The study results show that the SPUR approach can improve and train students in solving math problems. Mathematical representation ability is one of the abilities that students must have in order to easily present the solution to a problem.
\end{abstract}

Keywords: Mathematical Representation Ability, SPUR Approach, Education, Mathematics.

\section{PENDAHULUAN}

Matematika adalah ilmu global yang penggunaanya berlaku dalam kehidupan manusia dan menempati aspek vital dalam berbagai disiplin ilmu. Dalam Pendidikan, pembelajaran matematika 
wajib diajarkan mulai dari jenjang Pendidikan tingkat dasar hingga Pendidikan tingkat tinggi. Membentuk peserta didik dalam terampil berpikir analitis, logis, sistematis, kritis, inovatif dan kreatif adalah tujuan sampai saat ini yang diusahakan perwujudannya.

Unsur-unsur dari kemampuan representasi matematis dapat dipresentasikan menggunakan sebuah pendekatan. Pendekatan multidimensional yakni pendekatan SPUR adalah pendekatan yang dibangun oleh 4 dimensi pemahaman yaitu Skill, Properties, Uses, and Representaion (Thompson, Kaur, \& Bleiler, 2013), dimana empat dimensi tersebut saling terkait dan terhubung untuk menjadi suatu pemahaman yang kukuh.

Berdasarkan yang termuat dalam (OECD, 2013) bahwa terdapat 7 kemampuan matematika yang dikelompokkan berdasarkan komponen prosesnya yakni: 1) Kemampuan Komunikasi (Communication), siswa mampu memahami dan menuliskan proses dalam memperoleh solusi serta siswa mampu memberikan kesimpulan dari hasil yang didapatkannya; 2) Kemampuan Matematisasi (Mathematising), Siswa mampu menggunakan pemahaman konteks untuk menyelesaikan suatu masalah matematika; 3) Kemampuan Representasi (Representation), siswa mampu mengaitkan dan mengaplikasikan berbagai representasi dalam menyelesaikan permasalahan nyata; 4) Kemampuan Penalaran dan Argumen (Reasoning and Argument), siswa dapat memberikan alasan pembenaran yang logis dalam proses dan prosedur yang dipakainya saat menyelesaikan atau menghasilkan solusi yang matematis, siswa dapat membuat kesimpulan dari berbagai dalih yang matematis; 5) Kemampuan Merumuskan Strategi untuk Memecahkan Masalah (Devising Strategies) Siswa mampu menggunakan bentuk baku dari definisi dan aturan dalam matematika, siswa mampu menyusun siasat atau strategi dari berbagai aturan dan prosedur yang dapat mengarahkan menuju solusi dalam memecahkan masalah matematika; 6) Kemampuan Menggunakan Bahasa Simbolik (Using Symbol), siswa mampu menggunakan bentuk baku dari definisi dan aturan dalam matematika dan mengaplikasikan simbol-simbol matematika dalam memecahkan masalah; 7) Kemampuan Menggunakan Alat-Alat Matematika (Using mathematics tool), siswa mampu memanfaatkan alat-alat matematika sebagai media dalam menggambarkan hubungan dan struktur matematis.

Sebagaimana dikemukakan (Bleiler \& Thompson, 2013) SPUR adalah singkatan dari Skill, Properties, Uses dan Representation. Skill, yakni menggunakan satu atau lebih prosedur dalam algoritma untuk menyelesaikan masalah matematika. Properties, yakni menggunakan sifat dalam menyelesaikan masalah juga menyimpulkan hasil matematika. Uses, menggunakan dan mengaplikasikan model dalam menggambarkan dan menyelesaikan masalah nyata matematika; Representation, penggambaran visual dari konsep matematika. 


\section{METODE PENELITIAN}

Metode dalam literature review ini menerapkan strategi secara komperhensif, dengan melakukan penelusuran artikel pada database jurnal penelitian, dan melakukan tinjauan ulang artikel. Pencarian database tersebut meliputi Google Scholar, Scopus yang tersedia pada aplikasi Publish or Perish 7. Penelusuran artikel ini menggunakan kata kunci yakni, kemampuan representasi matematis( mathematical representation ability) terdapat 19 artikel yang diperoleh dan 13 artikel yang dipilih berdasarkan kesesuaian topik, hasil studi dari setiap artikel dan keterbatasan yang terjadi.

\section{HASIL PENELITIAN DAN PEMBA- HASAN}

\section{Kemampuan Representasi Matematis}

NCTM (2000) menyebutkan bahwa representasi matematis akan memungkinkan siswa untuk: 1) membangun dan menerapkan representasi untuk mengatur dan mengkomunikasikan ide-ide matematika; 2) menerjemahkan dengan memilih bentuk representasi untuk memecahkan masalah; 3) Menggunakan representasi untuk memodelkan permasalahan dari berbagai fenomena fisik, sosial, dan matematika.

Representasi matematis terdiri dari representasi visual dan non visual. Representasi visual meliputi grafik, tabel, sketsa/gambar, dan diagram; representasi non visual meliputi representasi numerik, dan persamaan matematis atau model matematis. Fokus penelitian pada representasi matematis non visual yakni siswa harus terbiasa dengan berbagai representasi seperti menggambar bendabenda fisik, bagan, grafik, simbol, dan model matematika. Siswa menggunakan representasi ini untuk mengatur dan mengkomunikasikan pemikiran mereka tentang ide-ide matematika (NCTM, 2000). Tanpa mengerahkan representasi, siswa tidak akan mudah menyelesaikan berbagai masalah aljabar, geometri, dan persamaan linier karena mereka tidak dapat dengan mudah membayangkan masalah tanpa merepresentasikannya terlebih dahulu.

Untuk mengukur representasi matematis siswa, penelitian (Minarni, 2016) menggunakan tes esai desain. Rangkaian rumusan tes yang dirancang berdasarkan aspek representasi matematis yakni; 1) Mewakili masalah cerita ke dalam bentuk simbolik atau persamaan matematis. 2) Membuat tabel untuk menyelesaikan masalah. 3) Membuat persamaan matematika dari informasi yang disajikan pada tabel, 4) Menggunakan grafik sebagai alat bantu untuk menyelesaikan masalah. 5) Membuat persamaan matematika dari grafik

Fazio et al. (2014) mengajukan tiga hipotesis tentang hubungan antara keterampilan non-simbolik, keterampilan simbolik, dan kemampuan matematis: (1) keterampilan non-simbolis berpengaruh tidak langsung terhadap prestasi belajar matematika. Artinya, anak-anak dengan keterampilan non-simbolis yang lebih baik memperoleh sistem numerik simbolik dengan lebih mudah, yang pada gilirannya meningkatkan kemampuan matematika mereka; (2) keterampilan non-simbolis memiliki efek langsung dan tidak langsung terhadap prestasi matematika; (3) keterampilan nonsimbolik dan simbolik secara independen 
Tabel 1. Artikel Terpilih

\begin{tabular}{|c|c|c|c|c|}
\hline Penulis & Judul & Sampel & Metode & Hasil \\
\hline $\begin{array}{l}\text { Septian et } \\
\text { al (2020) }\end{array}$ & $\begin{array}{l}\text { Mathematical } \\
\text { representation } \\
\text { ability throygh } \\
\text { geogebra-assisted } \\
\text { project-based } \\
\text { learning models }\end{array}$ & 55 & $\begin{array}{l}\text { Kuasi- } \\
\text { Eksperimental }\end{array}$ & $\begin{array}{l}\text { Pencapaian dan peningkatan } \\
\text { kemampuan representasi } \\
\text { matematis siswa lebih baik pada } \\
\text { model pembelajaran berbasis } \\
\text { proyek berbantuan GeoGebra } \\
\text { daripada yang menggunakan } \\
\text { model pembelajaran berbasis } \\
\text { proyek. }\end{array}$ \\
\hline $\begin{array}{l}\text { Maulyda et } \\
\text { al. (2019) }\end{array}$ & $\begin{array}{l}\text { Representation of } \\
\text { Trigonometry } \\
\text { Graph Funcsion } \\
\text { Colage Students } \\
\text { Using Geogebra }\end{array}$ & 30 & $\begin{array}{l}\text { Kualitatif } \\
\text { deskriptif }\end{array}$ & $\begin{array}{l}\text { (1) Hasil pekerjaan siswa } \\
\text { menggunakan tiga bentuk } \\
\text { representasi, yaitu a) representasi } \\
\text { verbal berupa kalimat, b) } \\
\text { representasi ekspresi matematika } \\
\text { terlihat dari penggunaan simbol } \\
\text { matematika dalam mewakili } \\
\text { tampilan Geogebra, dan c) } \\
\text { representasi visual berupa } \\
\text { bentuk gambar grafis (2) } \\
\text { Ekspresi matematika adalah } \\
\text { bentuk representasi yang paling } \\
\text { banyak digunakan oleh siswa, } \\
\text { sedangkan representasi yang } \\
\text { paling sedikit digunakan adalah } \\
\text { representasi visual. }\end{array}$ \\
\hline
\end{tabular}

\begin{tabular}{|c|c|c|c|}
\hline $\begin{array}{l}\text { Fitrianna et } \\
\text { al (2018) }\end{array}$ & $\begin{array}{l}\text { Mathematical } \\
\text { Representation } \\
\text { Ability of Senior } \\
\text { High } \quad \text { School } \\
\text { Students: An } \\
\text { Evaluation From } \\
\text { Students' } \\
\text { Mathematical } \\
\text { Disposition }\end{array}$ & $\begin{array}{l}\text { Kualitatif } \\
\text { dekriptif }\end{array}$ & $\begin{array}{lrr}\text { Hasil penelitian } & \text { menunjukkan } \\
\text { bahwa hampir } & \text { semua siswa } \\
\text { mampu } & \text { mengaplikasikan } \\
\text { representasi } & \text { visual } & \text { untuk } \\
\text { menyelesaikan } & \text { masalah } \\
\text { matematika, membangun model } \\
\text { matematika dan } & \text { menyelesaikan } \\
\text { masalah-masalah } & \text { dengan } \\
\text { melibatkan } & \text { simbol-simbol } \\
\text { matematika. } & \end{array}$ \\
\hline
\end{tabular}

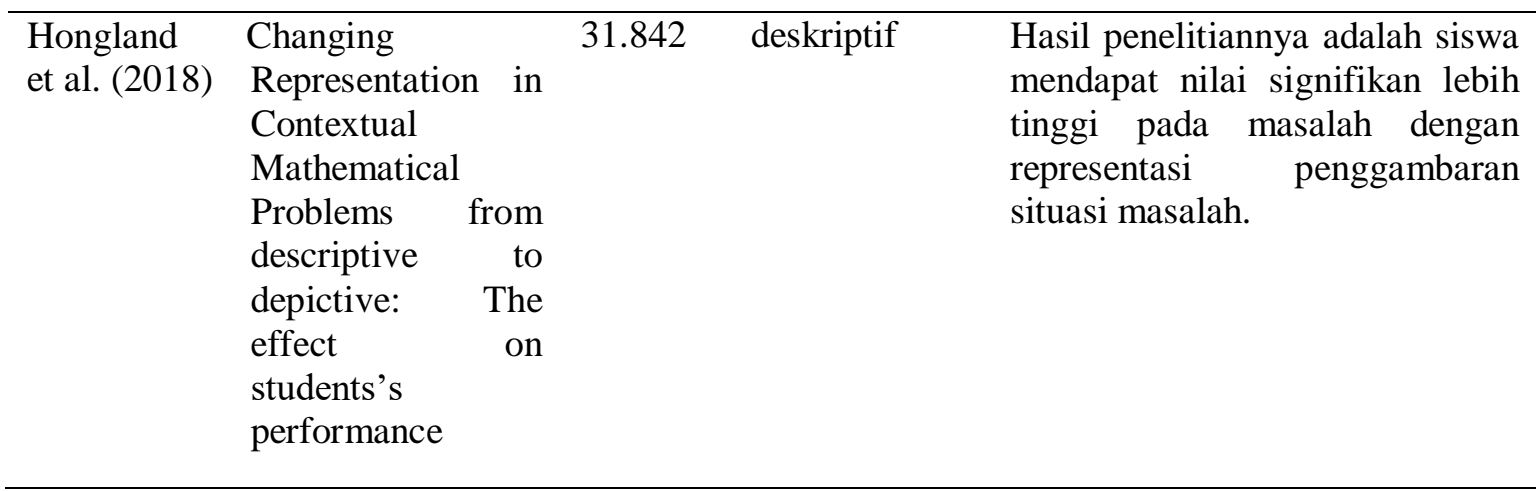




\begin{tabular}{|c|c|c|c|}
\hline $\begin{array}{l}\text { Sahendra et } \\
\text { al. (2018) }\end{array}$ & $\begin{array}{l}\text { Students' } \\
\text { Representation in } \\
\text { Mathematical } \\
\text { Word Problem- } \\
\text { solving: Exploring } \\
\text { Students' Self- } \\
\text { efficacy. }\end{array}$ & $\begin{array}{l}\text { kualitatif, } \\
\text { deskriptif }\end{array}$ & $\begin{array}{l}\text { Hasil penelitian menunjukkan } \\
\text { bahwa siswa dengan self-efficacy } \\
\text { tinggi cenderung menggunakan } \\
\text { representasi berganda dari sketsa } \\
\text { dan model matematika, } \\
\text { sedangkan siswa dengan self- } \\
\text { efficacy rendah cenderung } \\
\text { menggunakan representasi } \\
\text { tunggal sketsa atau model } \\
\text { matematika. }\end{array}$ \\
\hline
\end{tabular}

\begin{tabular}{|c|c|c|c|c|}
\hline $\begin{array}{l}\text { Nayir et al. } \\
(2018)\end{array}$ & $\begin{array}{l}\text { Investigating the } \\
\text { Readiness of } \\
\text { Students in } \\
\text { Primary Teacher } \\
\text { Education } \\
\text { Program Through } \\
\text { Verbal, Model and } \\
\text { Mathematical } \\
\text { Representations of } \\
\text { Number Sets }\end{array}$ & 61 & $\begin{array}{l}\text { Survei } \\
\text { Deskriptif }\end{array}$ & $\begin{array}{l}\text { Hasil penelitian menunjukkan } \\
\text { bahwa siswa Pendidikan Guru } \\
\text { SD memiliki tingkat kesiapan } \\
\text { yang rendah dalam himpunan } \\
\text { bilangan. Terlihat bahwa peserta } \\
\text { mengalami kesulitan dalam } \\
\text { mengekspresikan himpunan } \\
\text { dengan } \\
\text { matematika. }\end{array}$ \\
\hline $\begin{array}{l}\text { Hwang et } \\
\text { al. (2007) }\end{array}$ & $\begin{array}{l}\text { Multiple } \\
\text { representation } \\
\text { skills and } \\
\text { creativity effects } \\
\text { on mathematical } \\
\text { problem solving } \\
\text { using a } \\
\text { multimedia } \\
\text { whiteboard system }\end{array}$ & 25 & $\begin{array}{l}\text { Multimedia } \\
\text { sistem } \\
\text { papantulis }\end{array}$ & 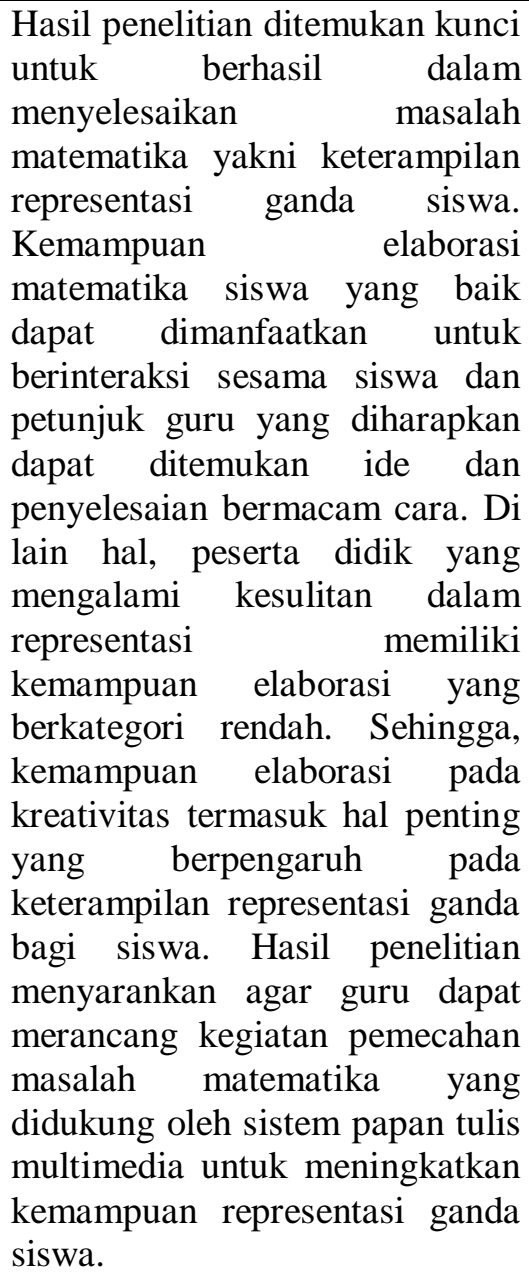 \\
\hline
\end{tabular}




\begin{tabular}{|c|c|c|c|}
\hline $\begin{array}{l}\text { Cartwiright. } \\
(2020)\end{array}$ & $\begin{array}{l}\text { Analyzing } \\
\text { students' } \\
\text { communication } \\
\text { and representation } \\
\text { of mathematical } \\
\text { fluency during } \\
\text { group tasks }\end{array}$ & Meta analisis & $\begin{array}{l}\text { Temuan menunjukkan bahwa } \\
\text { berbagai representasi yang } \\
\text { digunakan siswa bermanfaat } \\
\text { untuk mengamati kemahiran } \\
\text { matematika. Hasil ini } \\
\text { menunjukkan bahwa penilaian } \\
\text { lisan sebagai sarana untuk } \\
\text { memahami dan menafsirkan } \\
\text { kemahiran matematika siswa. }\end{array}$ \\
\hline
\end{tabular}

\begin{tabular}{|c|c|c|c|}
\hline $\begin{array}{l}\text { Minarni et } \\
\text { al (2016) }\end{array}$ & $\begin{array}{l}\text { Mathematical } \\
\text { understanding and } \\
\text { representation } \\
\text { ability of public } \\
\text { junior high school } \\
\text { in North Sumatra }\end{array}$ & Kualitatif & \begin{tabular}{lll} 
Berdasarkan tes esai yang \\
dilakukan, & \multicolumn{3}{c}{ kemampuan } \\
pemahaman matematis dan \\
representasi siswa berada di \\
kategori rendah.
\end{tabular} \\
\hline $\begin{array}{l}\text { Yanjun Li } \\
\text { et al (2018) }\end{array}$ & $\begin{array}{l}\text { Children's Non- } \\
\text { symbolic and } \\
\text { Symbolic } \\
\text { Numerical } \\
\text { Representations } \\
\text { and Their }\end{array}$ & 253 & $\begin{array}{l}\text { Hasil penelitian menunjukkan } \\
\text { bahwa keterampilan numerik } \\
\text { simbolik merupakan faktor } \\
\text { utama yang mempengaruhi } \\
\text { kinerja matematika pada anak } \\
\text { usia dini. }\end{array}$ \\
\hline
\end{tabular}

Associations with

Mathematical

Ability

\begin{tabular}{lllll}
\hline Ott et al & Multiple symbolic & 146 dan & Eksperimen & Hasilnya menunjukkan bahwa \\
$(2018)$ & representations: & 19 & & teks adalah satu-satunya \\
& The combination & representasi yang paling banyak \\
& of formula and & digunakan Penelitian ini \\
& text supports & menekankan pentingnya \\
& problem solving in & berbagai bentuk beberapa \\
& the mathematical & representasi dalam pembelajaran \\
& field of & & dan penilaian matematika.
\end{tabular}

propositional logic

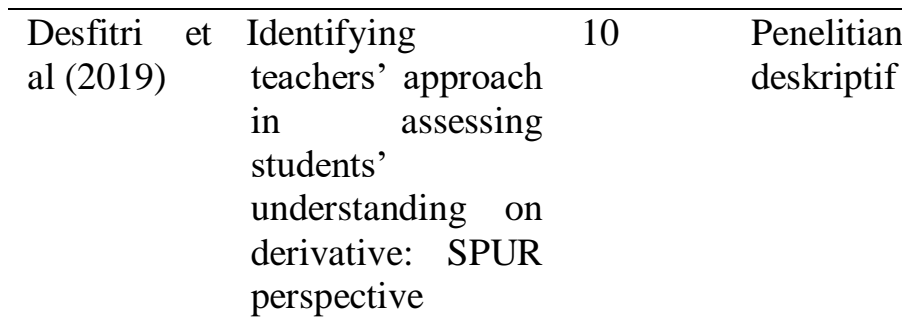




\begin{tabular}{|c|c|c|c|c|}
\hline & & & & $\begin{array}{l}\text { penggunaan, dan representasi) } \\
\text { untuk menilai pengetahuan } \\
\text { matematika siswa mereka. }\end{array}$ \\
\hline $\begin{array}{l}\text { Riyandiarto } \\
(2015)\end{array}$ & $\begin{array}{l}\text { Analisis } \\
\text { Pemahaman } \\
\text { Matematika Siswa } \\
\text { SMP dengan } \\
\text { Pendekatan } \\
\text { Multidimensi } \\
\text { SPUR (Skill, } \\
\text { Properties, Uses, } \\
\text { dan } \\
\text { Representation) }\end{array}$ & 27 & $\begin{array}{l}\text { metode } \\
\text { kualitatif } \\
\text { studi kasus }\end{array}$ & $\begin{array}{l}\text { Hasil penelitian menunjukkan 1) } \\
\text { Dimensi pemahaman Properties } \\
\text { dan Representations merupakan } \\
\text { dimensi dengan tingkat } \\
\text { pencapaian tertinggi sedangkan } \\
\text { dimensi Skills dan Uses } \\
\text { mengalami pencapaian terendah, } \\
\text { 2) Umumnya siswa melakukan } \\
\text { kesalahan di tiga tes dengan } \\
\text { pendekatan SPUR di objek } \\
\text { langsung matematik yakni fakta } \\
\text { dan keterampilan, 3) Menurut } \\
\text { pandangan etnisitas, perolehan } \\
\text { yang berbeda pada satu dimensi } \\
\text { cukup pada pemahaman yang } \\
\text { signifikan yaitu pada siswa } \\
\text { dengan etnis china dapat } \\
\text { menyelesaikan soal lebih baik } \\
\text { dalam pemahaman skill } \\
\text { dibanding siswa Jawa. }\end{array}$ \\
\hline
\end{tabular}

dapat mempengaruhi prestasi matematika secara keseluruhan. Dalam studi saat ini, kami menemukan efek tidak langsung dari keterampilan non-simbolis pada kemampuan matematika melalui keterampilan simbolik, yang mendukung hipotesis pertama Fazio et al. (2014).

\section{Pendekatan SPUR}

(Khaur \& Thompson, 2011) berpendapat bahwa keterampilan atau skill merupakan tingkat pemahaman terendah karena hanya mengukur kemampuan menghitung siswa. Tingkat selanjutnya adalah properties dimana menyajikan kemampuan siswa menggunkan sifat-sifat matematika dalam melakukan penyelesaian masalah. Kemudian tingkatan uses menampilkan kemampuan siswa dalam menghadapi dan menyelesaikan permasalahan dunia nyata.
Lalu pada tingkatan teratas representation yakni siswa dapat memiliki kemampuan menampilkan suatu permasalahan ke dalam bentuk visual, gambar, bagan, atau bentuk representasi lainnya. Menurut (Desfitri, 2019) Pendekatan SPUR untuk perspektif multidimensi pada pemahaman untuk menilai siswa pengetahuan matematika yaitu 1) Keterampilan, mewakili prosedur yang harus dikuasai siswa dengan lancar; mereka mulai dari penerapan algoritma standar hingga penemuan atau penemuan algoritma, termasuk prosedur dengan teknologi; 2) Sifat-sifat; Prinsip yang mendasari matematika, mulai dari penamaan properti yang digunakan untuk membenarkan kesimpulan untuk derivasi dan bukti; 3) Penggunaan; Aplikasi konsep ke dunia nyata atau konsep lain dalam matematika dan berkisar dari masalah dunia rutin 
hingga pengembangan dan penggunaan model matematika; 4) Representasi; Grafik, gambar, dan deskripsi visual lainnya dari konsep, termasuk representasi standar dari konsep dan hubungan dengan penemuan baru cara untuk merepresentasikan konsep.

\section{KESIMPULAN}

Representasi

matematika merupakan kemampuan yang mempunyai peran krusial bagi siswa dan merupakan bagian dari tujuan pembelajaran matematika yang butuh diraih. Representasi berguna untuk memfasilitasi siswa dalam menyelesaikan suatu masalah dengan cara yang efektif dan mudah. Representasi dapat bermanfaat sebagai alat mengkomunikasikan ide-ide matematika dari siswa kepada siswa lain dan guru. Pembelajaran matematika harus mengarahkan siswa untuk berlatih dan mengelaborasi kemampuan representasi matematis.

\section{DAFTAR PUSTAKA}

Desfitri, R., \& Vermana, L. (2019). Identifying teachers' approach in assessing students' understanding on derivative: SPUR perspective. Journal of Physics: Conference Series, 1157(4). https://doi.org/10.1088/17426596/1157/4/042114.

Fazio, L. K., Bailey, D. H., Thompson, C. A., \& Siegler, R. S. (2014). Relations of different types of numerical magnitude representations to each other and to mathematics achievement. Journal of Experimental Child Psychology, 123(1),

53-72. https://doi.org/10.1016/j.jecp.2014.0 1.013

Fitrianna, A. Y., Dinia, S., Mayasari, M., \& Nurhafifah, A. Y. (2018). Mathematical Representation Ability of Senior High School Students: An Evaluation from Students' Mathematical Disposition. JRAMathEdu (Journal of Research and Advances in Mathematics Education), $\quad 3(1), \quad 46$. https://doi.org/10.23917/jramathedu .v3i1.5872.

Hoogland, K., de Koning, J., Bakker, A., Pepin, B. E. U., \& Gravemeijer, K. (2018). Changing representation in contextual mathematical problems from descriptive to depictive: The effect on students' performance. Studies in Educational Evaluation, Vol. 58, Hal. 122-131. https://doi.org/10.1016/j.stueduc.20 18.06.004.

Hwang, W. Y., Chen, N. S., Dung, J. J., \& Yang, Y. L. (2007). Multiple representation skills and creativity effects on mathematical problem solving using a multimedia whiteboard system. Educational Technology and Society, 10(2), 191-212.

Li, Y., Zhang, M., Chen, Y., Deng, Z., Zhu, X., \& Yan, S. (2018). Children's non-symbolic and symbolic numerical representations and their associations with mathematical ability. Frontiers in Psychology, 9(JUN), 1-10. https://doi.org/10.3389/fpsyg.2018. 01035 .

Maulyda, M. A., Hidayanto, E., \& Rahardjo, S. (2019). Representation of Trigonometry Graph Funcsion Colage Students Using GeoGebra. International Journal of Trends in Mathematics Education Research, 
2(4), https://doi.org/10.33122/ijtmer.v2i4.

Minarni, A., Napitupulu, E. E., \& Husein, R. (2016). Mathematical understanding and representation ability of public junior high school in North Sumatra. Journal on Mathematics Education, 7(1), 4356.

https://doi.org/10.22342/jme.7.1.28 16.43-56.

Nayir, Ö. Y., Erhan, G. K., Koştur, M., Türkoğlu, H., \& Mirasyedioğlu, Ş. (2018). Investigating the readiness of students in primary teacher education program through verbal, model, and mathematical representations of number sets. Turkish Journal of Computer and Mathematics Education, 9(2), 249282.

https://doi.org/10.16949/turkbilmat. 331798.

NCTM. (2000). Principles and Standards for School Mathematics. United States of America : The National Council of Teachers of Mathematics, Inc.

OECD. (2013). PISA 2012 Assessment and Analytical Framework: Mathematics, Reading, Science, Problem Solving and Financial Literacy. PISA : OECD Publishing. https://www.oecd.org/pisaproducts/ PISA 2012 framework ebook_final.pdf.

Ott, N., Brünken, R., Vogel, M., \& Malone, S. (2018). Multiple symbolic representations: The combination of formula and text supports problem solving in the mathematical field of propositional logic. Learning and Instruction, Vol. 58, Hal. 88-105. https://doi.org/10.1016/j.learninstru c.2018.04.010.
Riyandiarto, B. B., Hidayah, I., \& Artikel, I. (2015). Analisis Pemahaman Matematika Siswa SMP Dengan Pendekatan Multidimensi SPUR (Skills, Properties, Uses, Dan Representations. Unnes Journal of Mathematics Education Research, 4(1),1-9.

https://journal.unnes.ac.id/sju/index. php/ujmer/article/view/6899.

Sahendra, A., Budiarto, M. T., \& Fuad, Y. (2018). Students' Representation in Mathematical Word ProblemSolving: Exploring Students' Selfefficacy. Journal of Physics: Conference Series, 947(1). https://doi.org/10.1088/17426596/947/1/012059.

Septian, A., Darhim, \& Prabawanto, S. (2020). Mathematical representation ability through geogebra-assisted project-based learning models. Journal of Physics: Conference Series, 1657(1). https://doi.org/10.1088/17426596/1657/1/012019.

Setiasih, E., Asikin, M., \& Mariani, S. (2019). Kemampuan Literasi Matematis Melalui Strategi REACT Berpendekatan SPUR. Prosiding Seminar Nasional Pascasarjana (Prosnampas), Vol. 2 No. 1. https://proceeding.unnes.ac.id/index .php/snpasca/article/download/344/ 365.

Siti Mawaddah, \& Anisah, H. (2015). Kemampuan Pemecahan Masalah Matematis Siswa Pada Pembelajaran Matematika Dengan Menggunakan Model Pembelajaran Generatif (Generatif Learning) di SMP. Jurnal Pendidikan Matematika. https://doi.org/10.1017/CBO978110 7415324.004 . 
| Jurnal PRIMATIKA, Volume 10, Nomor 2, Desember 2021

68 Literatur Review: Kemampuan Representasi Matematis Melalui Pendekatan SPUR

Hadijah - Stevanus Budi Waluya - Zaenuri 